\title{
Hafnium isotopic disequilibrium during sediment melting and assimilation
}

\author{
C. Zhang ${ }^{1,2}$, D. Liu ${ }^{1,3^{*}}$, X. Zhang ${ }^{4}$, C. Spencer ${ }^{5,6}$, \\ M. Tang ${ }^{7}$, J. Zeng ${ }^{1,2}$, S. Jiang ${ }^{8}$, M. Jolivet ${ }^{9}$, X. Kong $^{1,2}$
}

Abstract

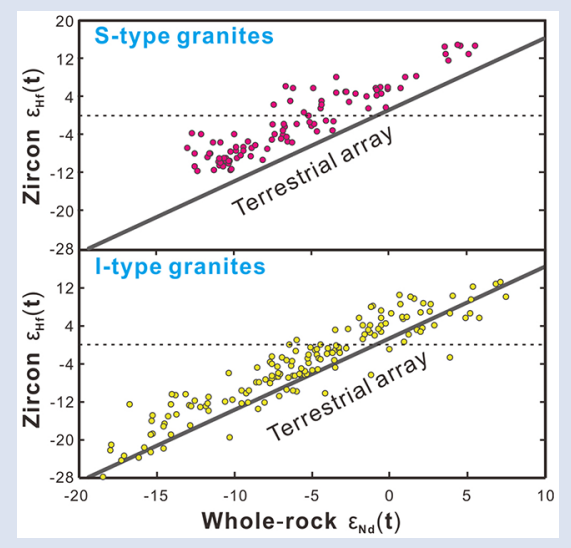

Identification of juvenile and mature crustal sources in granite formation relies on radiogenic isotopic systems such as $\mathrm{Sm}-\mathrm{Nd}$ and $\mathrm{Lu}-\mathrm{Hf}$ and assumes isotope systems reach equilibrium between the melt and residual phases prior to melt extraction. However, we hypothesise disequilibrium melting and residual zircon result in preferential retention of ${ }^{177} \mathrm{Hf}$ in residues, generating partial melts with higher ${ }^{176} \mathrm{Hf} /{ }^{177} \mathrm{Hf}$ ratios. To test this hypothesis, we evaluate radiogenic isotopic signatures of strongly-peraluminous granites from the Chinese Altai. These granites show Nd-Hf isotopic decoupling and inherited zircons with negative $\varepsilon_{H f}(t)$ values providing evidence for incomplete $H f$ release. This is consistent with the significant depletions in $\mathrm{Zr}$ and Hf. The Chinese data compilation shows that strongly-peraluminous and calcic to calc-alkalic, magnesian metaluminous or ferroan peraluminous (often respectively referred to as S- and I-type) granites show elevated $\varepsilon_{\mathrm{Hf}}(\mathrm{t})$ relative to the terrestrial $\mathrm{Hf}-\mathrm{Nd}$ isotopic array. Hf isotope disequilibrium marked by the preferential release of radiogenic Hf is likely ubiquitous during anatexis of zircon-rich protoliths.

Received 1 June 2019 | Accepted 24 November 2019 | Published 15 January 2020

\section{Introduction}

Strongly-peraluminous granites (SPG) generally indicate that partial melting of metasedimentary crustal rocks has been occurring throughout Earth's history (Harris et al., 2000; Appleby et al., 2010; Bucholz and Spencer, 2019). Experimental and geodynamic modelling have been applied to understanding the chemistry and physics of partial melting processes (Sawyer et al., 1991, 2011). It is assumed that crustal partial melts inherit the radiogenic isotope composition of their protoliths. Hafnium (Hf) is a geochemically important element in zircon because its isotopic composition is a sensitive tracer of crustal and mantle processes (Kemp et al., 2006). Zircon retains the initial melt isotopic composition because of its low $\mathrm{Lu} / \mathrm{Hf}$ ratio and refractory nature in sedimentary processes (Andersen et al., 2002). However, studies of SPG have shown the Hf isotopic composition of partial melts may not match the inferred magma source (Belousova et al., 2005; Villaros et al., 2012; Iles et al., 2019). Residual zircons, i.e. not dissolved during partial melting, may retain a significant amount of unradiogenic Hf (i.e. low ${ }^{176} \mathrm{Hf} /{ }^{177} \mathrm{Hf}$ ) causing the derivative crustal melts to have higher ${ }^{176} \mathrm{Hf} /{ }^{177} \mathrm{Hf}$ ratios relative to the bulk source (Farina et al., 2014). In such cases, source composition and melting conditions exert a first order control on $\mathrm{Hf}$ isotopic equilibrium during anatexis (Tang et al., 2014). To test the residual zircon effect on Hf isotopes in granitic rocks, we carried out a Nd-Hf-O isotopic study of SPG in the Chinese Altai. We then evaluate the generality of residual zircon effect in granitic magmatism using a compiled $\mathrm{Nd}-\mathrm{Hf}$ isotope database.

The Central Asian Orogenic Belt (CAOB) is Earth's largest Phanerozoic accretionary orogen (Kröner et al., 2014). The Chinese Altai is located in the central CAOB (Fig. S-1a), with $>40 \%$ of the exposed rocks being granites (Zhang et al., 2017). Previous studies dated CAOB plutons as Late Ordovician-Devonian (450 to $370 \mathrm{Ma}$ ) and Permian (280 to $270 \mathrm{Ma}$ ) and also report $\mathrm{Nd}-\mathrm{Hf}$ isotopic decoupling in these granites (e.g., Zhang et al., 2017). This paper reports new U-Pb

\footnotetext{
State Key Laboratory of Petroleum Resources and Prospecting, China University of Petroleum, Beijing, China

College of Geoscience, China University of Petroleum, Beijing, China

Unconventional Petroleum Research Institute, China University of Petroleum, Beijing, China

School of Earth Sciences and Gansu Key Laboratory of Mineral Resources in Western China, Lanzhou University, Lanzhou 730000, China

TIGeR (The Institute of Geoscience Research), School of Earth and Planetary Science, Curtin University, Perth, Australia

Department of Geological Sciences and Geological Engineering, Queen's University, Kingston, ON, Canada

Department of Earth, Environmental and Planetary Sciences, Rice University, Houston, TX, USA

Energy and Geoscience Institute, University of Utah, Salt Lake City, UT, USA

Géosciences Rennes, CNRS - Université Rennes 1, Rennes, France

Corresponding author (email: liudd@cup.edu.cn)
} 

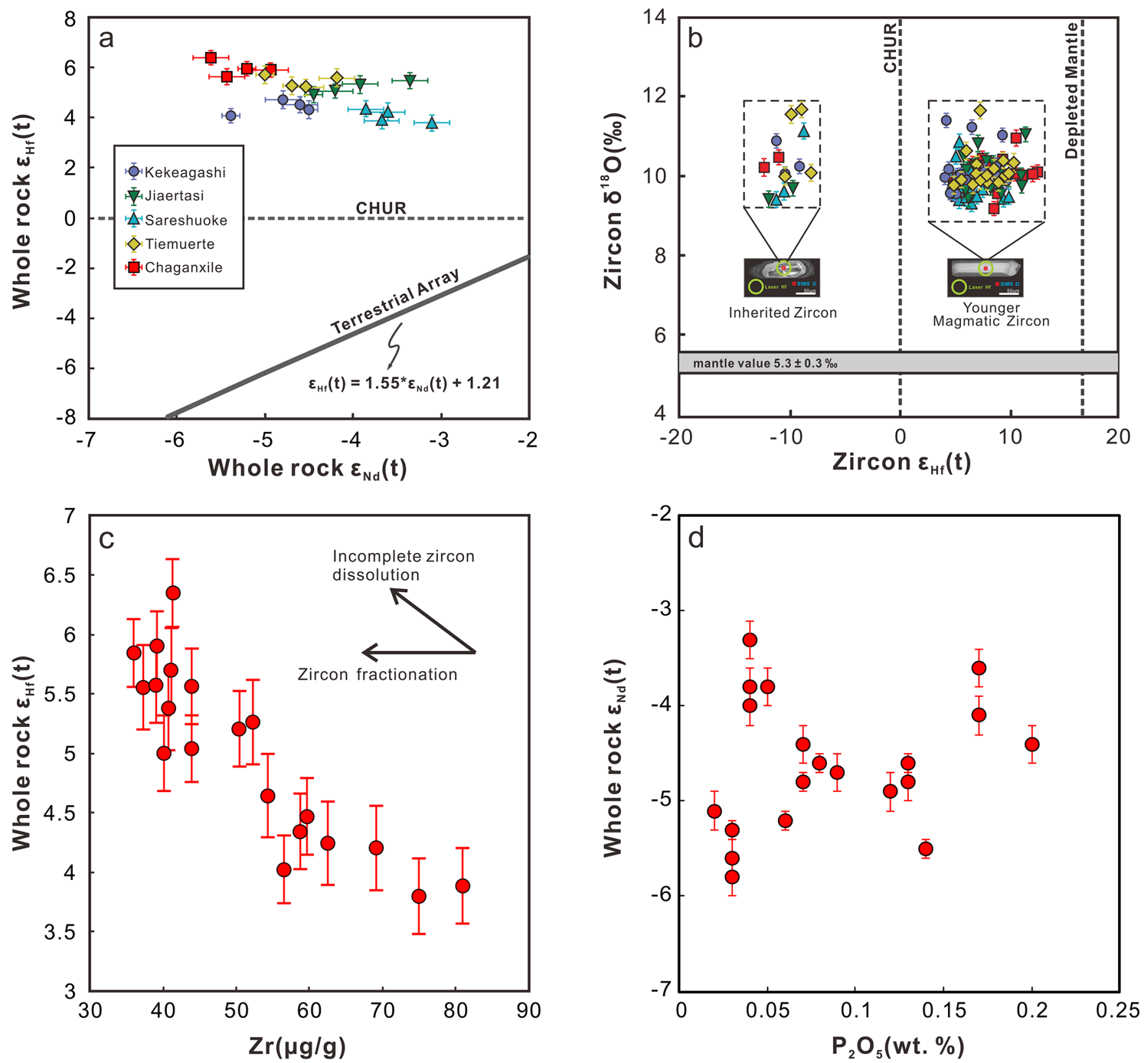

Figure 1 (a) $\varepsilon_{\mathrm{Hf}}(\mathrm{t})$ versus $\varepsilon_{\mathrm{Nd}}(\mathrm{t})$ for SPG in the Chinese Altai calculated based on U-Pb ages of the various plutons. Terrestrial array equations are from Vervoort et al. (2011). (b) Zircon $\varepsilon_{\mathrm{Hf}}(\mathrm{t})$ versus zircon $\delta^{18} \mathrm{O}$ for SPG in the Chinese Altai. Mantle values after Valley et al. (1998). Inherited zircons show $\varepsilon_{\mathrm{Hf}}(\mathrm{t})$ and $\delta^{18} \mathrm{O}$ values, indicating a metasedimentary source. Younger magmatic zircons show positive $\varepsilon_{\mathrm{Hf}}(\mathrm{t})$ values and similarly high $\delta^{18} \mathrm{O}$ values, CHUR-chondritic uniform reservoir. (c) $\varepsilon_{\mathrm{Hf}}(\mathrm{t})$ versus $\mathrm{Zr}(\mu \mathrm{g} / \mathrm{g})$. (d) $\varepsilon_{\mathrm{Nd}}(\mathrm{t})$ versus $\mathrm{P}_{2} \mathrm{O}_{5}$ (wt. \%). Uncertainties of all isotope measurements are internal $2 \sigma$.

ages, $\mathrm{Nd}-\mathrm{Hf}-\mathrm{O}$ isotopic compositions, major and trace element geochemistry, and $\mathrm{Hf}-\mathrm{O}$ isotopes of inherited zircons within SPG samples from the Chinese Altai with the aim of providing insights into SPG melting processes and isotope systematics.

\section{Methods and Results}

Granite samples from the Kekeagashi, Tiemuerte, Jiaertasi, Chaganxile, and Sareshuoke plutons in the Chinese Altai (Fig. S-1b) were analysed. In situ zircon U-Pb analysis was performed using laser ablation inductively coupled plasma mass spectrometry (ICP-MS). Whole rock (WR) major/trace element compositions were analysed using $\mathrm{X}$-ray fluorescence spectrometry and inductively coupled plasma mass spectrometry. $\mathrm{Nd}$ isotope measurements were conducted using a MAT-262 thermal ionisation mass spectrometer in static mode.
Hf isotope measurements were analysed using Nu Plasma II ICP-MS. In situ zircon Hf isotope analyses were conducted using a Thermo Scientific Neptune ICP-MS coupled to a 193-nm laser. In situ zircon O isotope analyses were conducted using a Cameca IMS-1280HR secondary ion mass spectrometer. Details of analytical methods are provided in Supplementary Information.

Zircon $\mathrm{U}-\mathrm{Pb}$ ages show granite crystallisation between 437 and $409 \mathrm{Ma}$ (Fig. S-2). U-Pb dating of inherited zircon cores indicate that Palaeozoic zircon grains seeded on significantly older crystals, with ages ranging from 3506 to $1990 \mathrm{Ma}$ (Fig. S-3). The WR $\varepsilon_{\mathrm{Nd}}(\mathrm{t})$ and $\varepsilon_{\mathrm{Hf}}(\mathrm{t})$ values range from -5.6 to -3.1 and +3.8 to +6.3 , respectively. The $\delta^{18} \mathrm{O}$ and $\varepsilon_{\mathrm{Hf}}(\mathrm{t})$ values of the magmatic zircon rims spanned from +9.2 to $+11.6 \%$ o and +4.0 to +12.3 , respectively. The $\delta^{18} \mathrm{O}$ values of zircon cores range from +9.3 to $+11.8 \%$ and $\varepsilon_{\mathrm{Hf}}(\mathrm{t})$ values from -12.4 to -8.2. Data are available in Tables S-1 and S-2. 


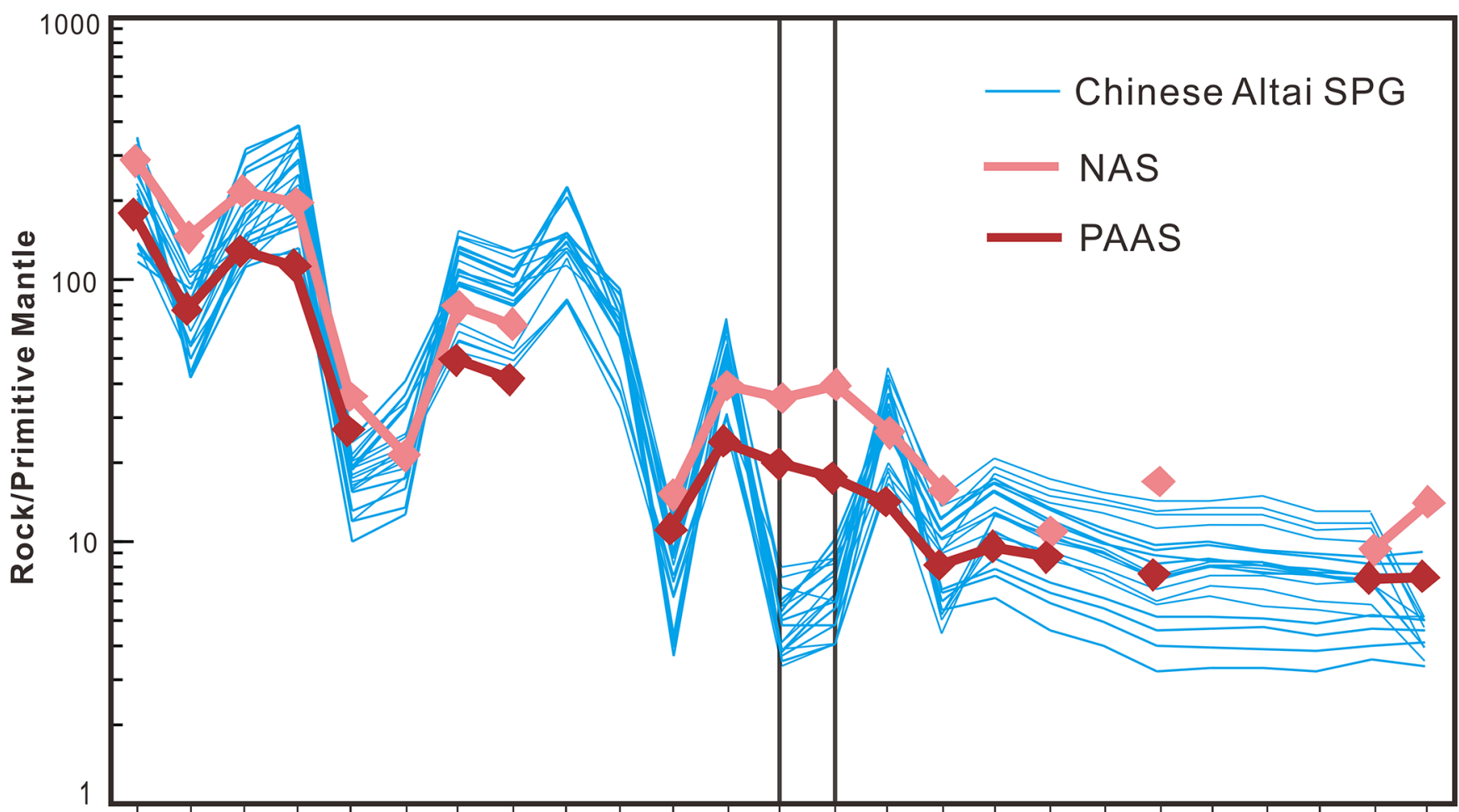

Rb Ba Th U Nb Ta La Ce Pb Pr Sr Nd Zr Hf Sm Eu Gd Tb Dy Y Ho Er Tm Yb Lu

Figure 2 Primitive mantle-normalised trace element spider patterns of the studied granites, PAAS and NAS. Normalisation data from Sun and McDonough (1989). Note the Zr-Hf depletions of the SPG from this study. All the data are listed in Table S-4.

\section{Discussion and Implications}

High $\delta^{18} \mathrm{O}$ values $\left(+9.2\right.$ to $+11.6 \%$ ), low $\varepsilon_{\mathrm{Nd}}(\mathrm{t})$ values $(-5.6$ to -3.1$)$, strongly-peraluminous character $(\mathrm{A} / \mathrm{CNK}=1.1-1.3)$, presence of aluminous minerals (i.e. garnet, sillimanite, cordierite, and muscovite; Fig. S-4), and low $\mathrm{Fe}, \mathrm{Mg}$, $\mathrm{Ca}$, and $\mathrm{Na}$ contents are consistent with derivation of melted sediment (Chappell and White, 1974).

The highly radiogenic Hf isotopes of these SPG and $\mathrm{Nd}-\mathrm{Hf}$ isotopic decoupling (Fig. 1a) give contradictory implications as to the contributions of isotopically depleted and enriched materials. It is feasible that $\mathrm{Nd}-\mathrm{Hf}$ isotopic decoupling is either highlighting differential source signature or caused by crustal melting processes. Mineral sorting effects during sediment transport can concentrate zircon in coarse-grained sedimentary rocks while fine-grained, clay-rich rocks are nearly devoid of zircon (Carpentier et al., 2009). Consequently, zircon-depleted sediments tend towards radiogenic Hf isotope signatures, while zircon-rich sediments generally have unradiogenic Hf isotope compositions. Melting of fine-grained, zircon-poor sedimentary rocks is likely to produce magmas with radiogenic $\mathrm{Hf}$ isotope compositions relative to their $\mathrm{Nd}$ isotope composition and account for a negative correlation between magma $\varepsilon_{\mathrm{Hf}}(\mathrm{t})$ and $\mathrm{Zr}$ concentration (Fig. 1c). However, we suggest that this mechanism is unlikely to be responsible for isotopic decoupling in the investigated granites as; 1) the sedimentary rocks in the studied area are sandstones and mudstones that are enriched in zircon and have moderate to low $\mathrm{Nd} / \mathrm{Hf}$ ratios (from 0.8 to 3.8, Long et al., 2008); 2) finegrained clastic sedimentary proxies (Post-Archean Australian Shales [PAAS] and North American Shales [NAS]), are not depleted in $\mathrm{Zr}$ and Hf while SPG of the Chinese Altai are depleted in $\mathrm{Zr}$ and Hf (Fig. 2); 3) inherited zircon cores are abundant in SPG, suggesting the source is not zircon-depleted. Thereby, we therefore conclude that radiogenic Hf isotopes are not source signatures nor is $\mathrm{Nd}-\mathrm{Hf}$ isotopic decoupling due to melting of zircon-poor fine-grained sediments.
$\mathrm{Nd}-\mathrm{Hf}$ isotopic decoupling may also be generated by disequilibrium melting with incomplete zircon dissolution (Fig. S-5; Zeng et al., 2005; Farina et al., 2014; Tang et al., 2014; Iles et al., 2018). Because Hf diffusion in zircon is slow under crustal melting conditions (Watson and Harrison, 1983), Hf isotope equilibrium during crustal anatexis is largely controlled by zircon dissolution. Inherited zircons in our samples are evidence of incomplete zircon dissolution during anatexis. Residual zircon in magma sources can retain unradiogenic Hf (i.e. low ${ }^{176} \mathrm{Hf} /{ }^{177} \mathrm{Hf}$ ) and may produce partial melts with elevated $\varepsilon_{\mathrm{Hf}}(\mathrm{t})$ relative to the source. This model explains $\mathrm{Hf}$ isotope variability recorded by zircon crystallising during partial melting and inherited zircon dissolution. This may generate melt batches with variable Hf isotope compositions, even if melts come from a single source (Tang et al., 2014). This single source melting scenario is supported by the zircon $\mathrm{O}$ isotopic compositions for the Chinese Altai granites. If the variation in zircon $\mathrm{Hf}$ isotopic composition is due to mixing between mantle-derived magmas and metasedimentary materials, negative correlations between zircon $\varepsilon_{\mathrm{Hf}}(\mathrm{t})$ and zircon $\delta^{18} \mathrm{O}$ (Kemp et al., 2007) are expected. However, Chinese Altai granites show similar $\delta^{18} \mathrm{O}$ (cores: +9.3 to $+11.8 \%$; rims: +9.2 to $+11.6 \%$ ) despite the large Hf isotopic variation (>20 epsilon units; Fig. 1b).

Disequilibrium melting with residual zircon can explain strong $\mathrm{Zr}$ and Hf depletions in the Chinese Altai granites (Fig. 2) as zircon hosts most Zr and Hf. More importantly, the WR and zircon $\varepsilon_{\mathrm{Hf}}(\mathrm{t})$ values of SPG correlate negatively with Zr concentrations (Fig. 1c), which is expected if residual zircon controls Hf isotopes and $\mathrm{Zr}$ and $\mathrm{Hf}$ concentrations in partial melts. Zircon fractionation during magma differentiation may also cause $\mathrm{Zr}$ and Hf depletions, but would not produce negative correlations between $\mathrm{Hf}$ isotopic composition and $\mathrm{Zr}$ concentration.

$\mathrm{Nd}$ concentrations in the melt and residue are dominantly controlled by apatite and monazite (Zeng et al., 2005). $\mathrm{Nd}$ isotopes may be affected by disequilibrium melting with 


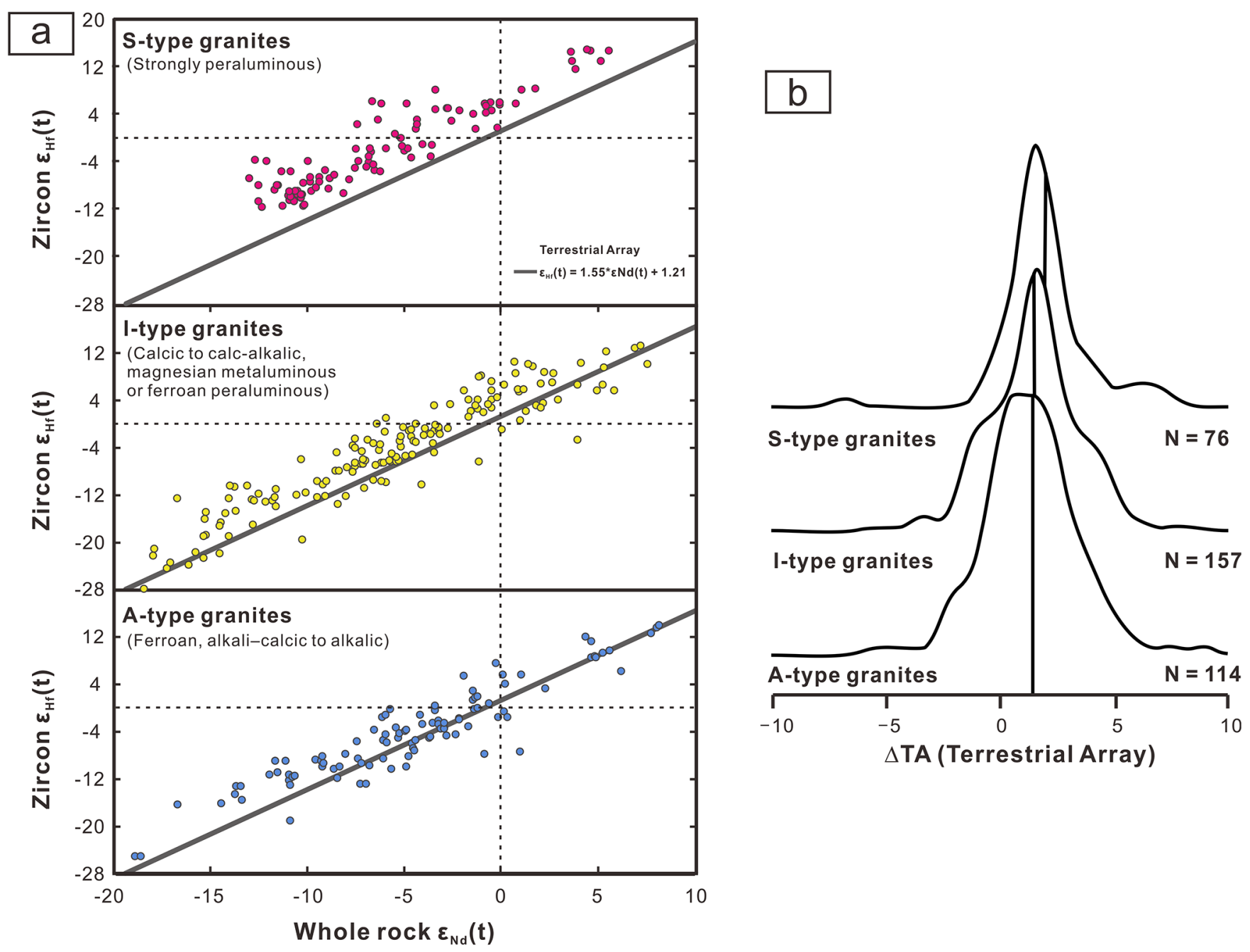

Figure 3 (a) Compilation of published neodymium and hafnium isotopic compositions of I-type, A-type, and S-type granites (as defined in the figure). Points represent average zircon values from single plutons. References listed in Table S-3. (b) Distance from the terrestrial array (TA) expressed as $\Delta \mathrm{TA}$ calculated for the three granite groups. Vertical line represents the median of all of the samples and demonstrate an increasing shift towards greater Hf disequilibrium (above the TA) with increasing aluminousity.

residual apatite and monazite. However, zircon has extremely low Lu/Hf and thus strongly fractionates Hf from Lu while apatite and monazite only moderately fractionate $\mathrm{Nd}$ and $\mathrm{Sm}$. Therefore, Hf isotopes are more sensitive to disequilibrium melting than $\mathrm{Nd}$ isotopes even if both zircon and P-bearing accessory minerals are present in the residues. This is supported by the observation that $\varepsilon_{\mathrm{Hf}}(\mathrm{t})$ strongly correlates with $\mathrm{Zr}$ concentration while $\varepsilon_{\mathrm{Nd}}(\mathrm{t})$ varies independently from $\mathrm{P}_{2} \mathrm{O}_{5}$ in our samples (Fig. 1d). We suggest that Nd-Hf decoupling of Altai SPG is caused by the Hf isotopic disequilibrium and incomplete zircon dissolution during sediment melting. Mineral sorting might have a minor contribution to isotopic decoupling in zircon-rich sources.

To evaluate the generality of residual zircon effects in granitic magmatism, we compiled a database of Chinese granite $\mathrm{Nd}-\mathrm{Hf}$ isotope compositions. Nd-Hf isotopic decoupling is present in SPG with systematically elevated $\varepsilon_{\mathrm{Hf}}(\mathrm{t})$ relative to the terrestrial $\mathrm{Nd}-\mathrm{Hf}$ isotope array (TA) and is also present to a lesser degree in I-type (calcic to calc-alkalic, magnesian metaluminous or ferroan peraluminous) granites (Fig. 3). This is in contrast to A-type (ferroan, alkali-calcic to alkalic) granites that overlap with the TA. We calculated minimum temperatures required to dissolve zircon completely in the source rocks (Fig. 4). We assume the melting degree to be $\sim 30 \%$ (Petford et al., 2000). Our calculation shows that, for peraluminous melts $(\mathrm{M}>1.1)$, complete zircon dissolution would require $>950{ }^{\circ} \mathrm{C}$ if the source contains $>200 \mu \mathrm{g} / \mathrm{g}$ $\mathrm{Zr}$, which appears to be too high for most SPG systems. Considering that the average PAAS and NAS contains 210 and $200 \mu \mathrm{g} / \mathrm{g} \mathrm{Zr}$, respectively (Gromet et al., 1984; Taylor and McLennan, 1985), residual zircon seems to be inevitable if the source rocks are detritus-rich sedimentary rocks. I-type granites also deviate from the TA to a lesser degree than SPG but greater than A-type granite implying sediment assimilation in typical arc settings (Fig. 3). We suggest that may also be explained by a residual zircon effect if zircon is present in the sources of I-type granites.

These findings raise questions to the utility of $\mathrm{Hf}$ isotopes in quantifying crustal recycling as disequilibrium melting and residual zircon may lead to radiogenic Hf isotopes in the partial melts that falsely indicate juvenile sources. Therefore, Hf isotopes of SPG and I-type granites may not faithfully reflect the protoliths. Hf isotopes biased by residual zircon may lead to erroneous conclusions in detrital zircon studies as petrogenetic context is missing. Rates of crustal reworking can be significantly underestimated if only $\mathrm{Hf}$ isotopes are applied. Therefore, caution is needed when using detrital zircon Hf isotopes to reconstruct the net growth of the continental crust. 


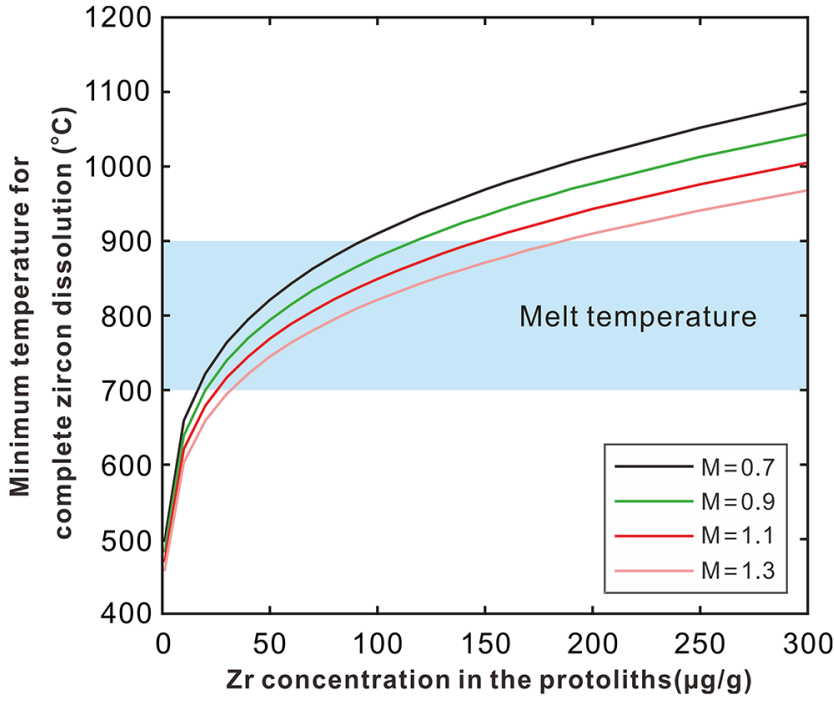

Figure 4 Calculated minimum melt temperature for zircon dissolution as a function of $\mathrm{Zr}$ concentration in the protoliths and $M$ value (cation ratio). SPG have $M$ values $>1.1$ while I-type granites typically have $\mathrm{M}$ values $<1.0$. Melt $\mathrm{Zr}$ concentration at zircon saturation using the zircon saturation model of Boehnke et al. (2013).

\section{Acknowledgements}

The manuscript was greatly improved by constructive reviews from Claire Bucholz, Kieran Iles and an anonymous reviewer and the editor, Horst R. Marschall. We thank William L. Griffin, Keda Cai for the valuable discussions. This work is financially supported by the grants from the National Natural Science Foundation of China (No. 41502209), and the National Science and Technology Major Project (No. 2016ZX05034-001, 2017ZX05035-002).

\section{Editor: Horst R. Marschall}

\section{Additional Information}

Supplementary Information accompanies this letter at http:// www.geochemicalperspectivesletters.org/article2001.

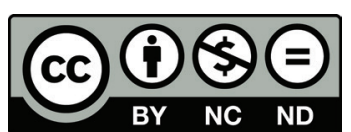

This work is distributed under the Creative Commons Attribution Non-Commercial No-Derivatives 4.0 License, which permits unrestricted distribution provided the original author and source are credited. The material may not be adapted (remixed, transformed or built upon) or used for commercial purposes without written permission from the author. Additional information is available at http://www.geochemicalperspectivesletters.org/ copyright-and-permissions.

Cite this letter as: Zhang, C., Liu, D., Zhang, X., Spencer, C., Tang, M., Zeng, J., Jiang, S., Jolivet, M., Kong, X. (2020) Hafnium isotopic disequilibrium during sediment melting and assimilation. Geochem. Persp. Let. 12, 34-39.

\section{References}

ANDERSEN, T. (2002) Correction of common lead in U-Pb analyses that do not report ${ }^{204} \mathrm{~Pb}$. Chemical Geology 192, 59-79.
Appleby, S.K., Gillespie, M.R., Graham, C.M., Hinton, R.W., Oliver, G.J.H., KELLY, N.M. (2010) Do S-type granites commonly sample infracrustal sources? New results from an integrated $\mathrm{O}, \mathrm{U}-\mathrm{Pb}$ and $\mathrm{Hf}$ isotope study of zircon. Contributions to Mineralogy and Petrology 160, 115-132.

Belousova, E.A., Griffin, W.L., O’Reilly, S.Y. (2005) Zircon crystal morphology, trace element signatures and Hf isotope composition as a tool for petrogenetic modelling: examples from Eastern Australian granitoids. Journal of Petrology 47, 329-353.

Boehnke, P., Watson, E.B., Trail, D., Harrison, T.M., Schmitt, A.K. (2013) Zircon saturation re-revisited. Chemical Geology 351, 324-334.

Bucholz, C.E., Spencer, C.J. (2019) Strongly peraluminous granites across the Archean-Proterozoic transition. Journal of Petrology 60, 1299-1348.

Carpentier, M., Chauvel, C., Maury, R.C., Mattielli, N. (2009) The "zircon effect" as recorded by the chemical and Hf isotopic compositions of Lesser Antilles forearc sediments. Earth and Planetary Science Letters 287, 86-99.

Chappell, B., White, A. (1974) Two contrasting granite types. Pacific Geology $8,173-174$.

Farina, F., Stevens, G., Gerdes, A., FreI, D. (2014) Small-scale Hf isotopic variability in the Peninsula pluton (South Africa): the processes that control inheritance of source ${ }^{176} \mathrm{Hf} /{ }^{177} \mathrm{Hf}$ diversity in S-type granites. Contributions to Mineralogy and Petrology 168, 1065.

Gromet, L.P., HAskin, L.A., KoroteV, R.L., DymeK, R.F. (1984) The "North American shale composite": Its compilation, major and trace element characteristics. Geochimica et Cosmochimica Acta 48, 2469-2482.

Harris, N., VANCE, D., AYres, M. (2000) From sediment to granite: timescales of anatexis in the upper crust. Chemical Geology 162, 155-167.

Iles, K.A., Hergt, J.M., Woodhead, J.D. (2018) Modelling isotopic responses to disequilibrium melting in granitic systems. Journal of Petrology 59, 87-113

Iles, K.A., Hergt, J.M., Woodhead, J.D. (2019) Petrogenesis of granitoids from the Lachlan Fold Belt, southeastern Australia: the role of disequilibrium melting. Gondwana Research https://doi.org/10.1016/j. gr.2019.08.011.

Kemp, A.I.S., Hawkesworth, C.J., Paterson, B.A., Kinny, P.D. (2006) Episodic growth of the Gondwana supercontinent from hafnium and oxygen isotopes in zircon. Nature 439, 580.

Kemp, A.I.S., Hawkesworth, C.J., Foster, G.L., Paterson, B.A., Woodhead, J.D., Hergt, J.M., Gary, C.M., Whitehouse, M.J. (2007) Magmatic and crustal differentiation history of granitic rocks from Hf-O isotopes in zircon. Science 315, 980-983.

Kröner, A., Kovach, V., Belousova, E., Hegner, E., Armstrong, R., Dolgopolova, A., Seltmann, R., Alexeiev, D.V., Hoffmann, J.E., Wong, J., Sun, M., CaI, K., Wang, T., Tong, Y., Wilde, S.A., DEGTYAREV, K.E., RYTSK, E. (2014) Reassessment of continental growth during the accretionary history of the Central Asian Orogenic Belt. Gondwana Research 25, 103-125.

Long, X.P., Sun, M., YuAn, C., XIAO, W.J., CAI, K.D. (2008) Early Paleozoic sedimentary record of the Chinese Altai. implications for its tectonic evolution. Sedimentary Geology 208, 88-100.

Petford, N., Cruden, A.R., Mccaffrey, K.J., Vigneresse, J.L. (2000) Granite magma formation, transport and emplacement in the Earth's crust. Nature $408,669-673$

SAWYER, E.W. (1991) Disequilibrium melting and the rate of melt-residuum separation during migmatization of mafic rocks from the Grenville Front, Quebec. Journal of Petrology 32, 701-738.

SAWYer, E.W., CESARE, B., Brown, M. (2011) When the Continental Crust Melts. Elements 7, 229-234

Sun, S.S., McDonougH, W.F. (1989) Chemical and isotopic systematics of oceanic basalts: implications for mantle composition and processes. Geological Society, London, Special Publications 42, 313-345.

TANG, M., WANG, X.L., ShU, X.J., WAnG, D., YAng, T., Gopon, P. (2014) Hafnium isotopic heterogeneity in zircons from granitic rocks: Geochemical evaluation and modeling of "zircon effect" in crustal anataxis. Earth and Planetary Science Letters 389, 188-199.

TAYLOR, S.R., MCLEnNAN, S.M. (1986) The chemical composition of the Archaean crust. Geological Society, London, Special Publications 24, 173-178.

Valley, J.W., Kinny, P.D., Schulze, D.J., SpicuzzA, M.J. (1998) Zircon megacrysts from kimberlite: oxygen isotope variability among mantle melts. Contributions to Mineralogy and Petrology 133, 1-11.

Vervoort, J.D., Plank, T., Prytulak, J. (2011) The Hf-Nd isotopic composition of marine sediments. Geochimica et Cosmochimica Acta 75, 5903-5926. 
Villaros, A., Buick, I.S., Stevens, G. (2012) Isotopic variations in S-type granites: an inheritance from a heterogeneous source? Contributions to Mineralogy and Petrology 163, 243-257.

WATSON, E.B., HARRISON, T.M. (1983) Zircon saturation revisited: temperature and composition effects in a variety of crustal magma types. Earth and Planetary Science Letters 64, 295-304.

Zeng, L., Asimow P.D., SAleeby J.B. (2005) Coupling of anatectic reactions and dissolution of accessory phases and the $\mathrm{Sr}$ and $\mathrm{Nd}$ isotope systematics of anatectic melts from a metasedimentary source. Geochimica et Cosmochimica Acta 69, 3671-3682.

Zhang, C., LiU, L.F., Santosh, M., Luo, Q., Zhang, X. (2017) Sediment recycling and crustal growth in the Central Asian Orogenic Belt Evidence from $\mathrm{Sr}-\mathrm{Nd}-\mathrm{Hf}$ isotopes and trace elements in granitoids of the Chinese Altay. Gondwana Research 47, 131-141. 